Z. klin. Chem. u. klin. Biochem.

8. Jg., S. $354-360$, Juli 1970

\title{
Normal Values for the Various 17-Oxosteroids, Pregnanes and Testosterone Excreted in the Urine of Healthy Boys and Girls
}

\author{
By H. Berger, M. Fink, H. J. Fritz ${ }^{1}$ ), H. Gleispach, P. HeidemanN ${ }^{1}$ ) and J. Wolf ${ }^{1}$ ) \\ Department of Pediatrics, University of Innsbruck (Austria)
}

(Eingegangen am 23. Februar 1970)

\begin{abstract}
The excretion of the most important 17-oxosteroids, the pregnanes and testosterone was studied by gas-liquid-chromatography. Twenty-four-hour urine specimens were collected from 350 healthy persons of both sexes, ranging in the age from four to twenty years. The values are ordered according to the bone age of the children. During the entire process of maturation we find a continuous increase of the steroids measured, the greatest increase commencing after the tenth year of age, starting somewhat earlier in girls than in boys. Correlations between the amounts excreted invite us to discuss the probability that this relationship is related to enzyme maturation.
\end{abstract}

Die Harnausscheidung der bedeutendsten 17-Oxosteroide, der Pregnane und von Testosteron wurde mittels Gaschromatographie untersucht. Bei 350 gesunden Personen beiderlei Geschlechts im Alter von 4 bis 20 Jahren wurden 24-Stdn.-Urine gesammelt. Die Werte wurden dem Knochenalter der Probanden entsprechend geordnet. Es fand sich ein ständiger Anstieg in der Steroidhormonausscheidung mit zunebmender Reifung, der maximale Anstieg erfolgt jedoch nach dem zehnten Lebensjahr, bei Mädchen etwas früher als bei Knaben. Korrelationen zwischen den ausgeschiedenen Mengen lassen uns die Möglichkeit einer Enzymreifung diskutieren.

\section{Introduction}

When we commenced the examination of steroid hormones in the urine of sick children by gas-liquidchromatography, we needed normal values as a base for the judgement of steroid patterns. The investigation of CAwLEY and associates (1), reports the excretion of hormones of twenty normal adults measured by gas-liquidchromatography. TANNER and Gupta (2) report a longitudinal study in children. Teller (3) observed the steroid pattern of boys and girls by paper chromatography. There were also the investigations of BLUNCK (4), Vestergard (5) and Paulsen (6) who measured some of the steroid hormones estimated by us with different methods. These values lie within the range determined by our investigation, but the number of healthy persons investigated is too small for the establishment of real normal values.

The steroid hormones ${ }^{2}$ ) in the urines of more than 350 boys and girls have been measured. We can be certain that our values demonstrate actual mean values and approximate to the correct range. We did not estimate

1) The experiments are done in conjunction with the doctorial these.

2) Steroids:

Androsterone . . . . . . 5a-Androstane-3aol-17one

Etiocholanolone ... 5 5-Androstane-3xol-17one

Dehydroepiandrosterone . . $\Delta 5$-Androstene-3Bol-17one

11-Oxoandrosterone . . . . 5 $\alpha$-Androstane-3 $\alpha$ ol-11,17dione

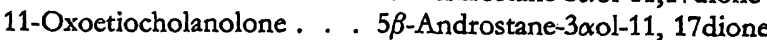

$11-\beta$-Hydroxyandrosterone . $5 \alpha$-Androstane- $3 \alpha, 11 \beta$ diol-17one

$11-\beta$-Hydroxyetiocholanolone $5 \beta$-Androstane- $3 \alpha, 11 \beta$ diol-17one

Testosterone . . . . . $\Delta 4$-Androstene-17- $\beta$ ol 3one.

Pregnanediol . . . . . . 5 $5 \beta$-Pregnane-3 $\alpha, 20$ diol

Pregnanetriol . . . . . 5 5 -Pregnane-3 $\alpha, 17 \alpha, 20$ triol

Pregnanetriolone . . . 5 5 -Pregnane-3 $\alpha, 17 \alpha, 20$ triol-11one the standard deviation because we believe that in the case of living material the calculation of a standard deviation would falsify the results. A standard deviation is quite right in the case of a range given by a method but not' when the range is caused by real differences in the excretion of healthy persons.

\section{Material and Methods}

Selection of children

Many factors such as hereditary and psychical ones as well as food and environment influence the development of a child. So we think, that it is necessary to choose healthy children with normal height and weight and also normal skeletal development and that clinic patients are less suitable for such an investigation. Seven boarding schools helped us in collecting the urines of boys and girls. From each person we estimated height and weight and also the skeletal age according to the atlas of GrEurich and PyLE (7) by a radiographic study of hand and wrist. Children whose somatic growth did not correspond with the normal range were eliminated. We grouped children according to the skeletal age as the best indicator for somatic growth.

\section{Collection of urine}

From each child we collected one or two 24-h-urines. Each portion of urine was immediately preserved with a bactericide as we found that the hormones are destroyed by bacteria even during the collection. The preservative consists of a mixture of $3 \mathrm{~N}$ sodium acetate buffer $\mathrm{pH} 4$, chloroform and boric acid. During our last investigation (unpublished) the use of this mixture proved better than that of sodium acetate buffer with chloroform as described by us (8) or the use of boric acid alone.

When the collection was finished the analysis was immediately carried out with one part of the urine, while the rest was deep frozen and used for a repeat analysis if the results were not clear.

Preparation of the urine and gas-liquid-chromatography of the steroids

For this procedure only the most important steps will be mentioned. Hydrolysis of the conjugates and extraction of urine: Only a part of the steroids are excreted unconjugated and since most of them 
are conjugated with glucuronic or sulfuric acid, they must be liberated. The urine is adjusted to $\mathrm{pH} 6$, a few drops of chloroform and 10,000 Fishman units of $\beta$-glucuronidase (EC 3.2.1.31) are added, and the urine is incubated for $24 \mathrm{~h}$ at $38^{\circ}$. After triple extraction with ether, the urine is brought to $\mathrm{pH} 1$ with $6 \mathrm{~N}$ $\mathrm{H}_{2} \mathrm{SO}_{4}$ and extracted continuously with ether at room temperature for $48 \mathrm{~h}$. The ether extracts are washed twice with $2 \mathrm{~N} \mathrm{Na}_{2} \mathrm{CO}_{3}$ and 3 times with water. Then the extracts are combined and evaporated to dryness.

Column chromatograpby: The dried extract is now purified by column chromatography. In addition to the purification, the 11deoxy-17-oxosteroids and testosterone are separated from the 11hydroxy-17-oxosteroids and the pregnanes. A glass column with $9 \mathrm{~mm}$ diameter is filled with benzene and $4 \mathrm{mg}$ neutral aluminium oxide, activity grade III. The urine extract is disolved in benzene and introduced into the column. The steroids are eluted by benzene with increasing portions of ethanol. Two fractions are collected.

The first contains:

androsterone, etiocholanolonc, dehydroepiandrosterone and testosterone.

The second contains:

11-oxo-androsterone, 11-oxo-etiocholanolone, 11- $\beta$-hydroxy-androsterone, 11- $\beta$-hydroxy-etiocholanolone, pregnanediol, pregnanetriol and pregnanetriolone, the latter being significant for 21hydroxylase-deficiency.

Formation of derivatives: For gas-liquid-chromatography we need derivates which are not destroyed by temperatures in the range of $260^{\circ}$ and which give good separation on the columns used.

We use the trimethylsilylethers (9). For routine analysis we use a mixture of hexamethyldisilazane and trimethylchlorosilane as silylating agent, for the estimation of very small amounts the highly active reagent bistrimethylsilylacetamide $(10,11)$ is used.

The internal standard is added to the two fractions, which are then dried. $0.5 \mathrm{~m} /$ hexamethyldisilazane and 3 drops of trimethylchlorosilane are added and the mixture is incubated for one hour at $65^{\circ}$. Thereafter the reaction mixture is dried in a dry stream of nitrogen.

Gas-liquid-chromatograpby: We use a fraktometer F 20 Perkin Elmer with a 2 meter glass column. For some special analyses we also use steel columns (12). The solid support is gaschrom-P coated with $3 \%$ XE 60 , column temperature $220^{\circ}$, flame ionization detector and injector at $260^{\circ}$, nitrogen at $50 \mathrm{ml} / \mathrm{min}$. is used as carrier.

The dried residue of the trimethylsilylether is dissolved in $0.2 \mathrm{ml}$ of $\mathrm{CCl}_{4}$ and 1 to $5 \mu l$ are injected.

The calculation of the steroids is performed by measuring peak height and width at half the height. In this way we obtain the peak area. The peak area of the unknown steroid is compared with that of the internal standard and using a calibration curve established for all steroids, the amount is calculated.

Accuracy: In another investigation (13) we discuss the problem of the accuracy of our own method. Only the most important facts will be reviewed.

a) For each steroid to be determined, known samples were added to urines in increasing amounts and a calibration curve was established. Each chromatogramm was evaluated following this calibration curve. In this manner losses are excluded.

b) CuRtrus and associates (14) showed that the hydrolysis and extraction method described in this investigation gives the best results and they observed no destruction of the steroids.

c) Some of the urines were measured twice and the greatest differences between the two analyses were less than $10 \%$ if the amounts were greater than $50 \mu \mathrm{g} / 24$ h-urine. The range was greater with smaller amounts. In routine analyses values under $10 \mu \mathrm{g}$ can only be estimated within a range of $50 \%$.

Summarizing, we can establish that the losses caused by bacterial destruction during the collection of the urines are prevented by a preservative and the losses in the extraction and the column chromatography are eliminated by a calibration curve.

\section{Results}

The following are the results obtained from different urines of a six and a half year old boy (table 1) whose skeletal age was four and a half. Several 24-hour-urine specimens were collected. In the first portion high values of 11-oxo-etiocholanolone and of 11- $\beta$-hydroxy-etiocholanolone and relatively large amounts of testosterone were found, but there was no detectable $11-\beta$-hydroxyandrosterone or dehydroepiandrosterone. The hormone excretion pattern half a year later was quite different. The time lapse could eventually be responsible for this change. However, the same fact does not explain the differences between the second and the third samples or urines that were collected in an interval of only two days.

Tab. 1

17-oxosteroids and pregnanes estimated in three different 24-hour specimens of the boy, R. P. chronological age: $6^{1} / 2$ years, bone age: $4^{1} / 2$ years 1. 11.67 10.5.68 25.5.68 $\mathrm{mea}^{\mathrm{n}}$

\begin{tabular}{|c|c|c|c|c|}
\hline $\begin{array}{l}\text { Androsterorie }(\mu \mathrm{g}) \\
\text { Etiocholanolone }(\mu \mathrm{g}) \\
\text { Dehydroepiandrosterone }(\mu \mathrm{g}) \\
11 \text {-Oxo-androsterone }(\mu \mathrm{g}) \\
11-\text { Oxo-etiocholanolone }(\mu \mathrm{g}) \\
11-\beta \text {-Hydroxy-androsterone }(\mu \mathrm{g}) \\
\text { 11- }- \text {-Hydroxy-etiocholanolone }(\mu \mathrm{g}) \\
\text { Testosterone }(\mu \mathrm{g}) \\
\text { Pregnanediol }(\mu \mathrm{g}) \\
\text { Pregnanetriol }(\mu \mathrm{g})\end{array}$ & $\begin{array}{r}111 \\
251 \\
109 \\
1050 ! \\
290 \\
17 \\
142 \\
248\end{array}$ & $\begin{array}{r}195 \\
74 \\
18 \\
147 \\
133 \\
83 \\
18 \\
9 \\
16 \\
159\end{array}$ & $\begin{array}{r}232 \\
162 \\
28 \\
48 \\
202 \\
39 \\
72 \\
2 \\
67 \\
15\end{array}$ & $\begin{array}{r}179 \\
162 \\
15 \\
101 \\
? \\
41 \\
127 \\
9 \\
75 \\
141\end{array}$ \\
\hline
\end{tabular}

Also these differences do not seem to have been due to an error in method as each determination was made in duplicate and the greatest differences between two analyses of the same sample were less than $20 \%$. We can certify that we found not only a circadian rhythm of the steroid secretion of the target glands but also great differences in the quantity of urinary hormone excretion measured in individual subjects on different occasions. The results obtained from a large number of persons, are given in table 2 and 3 . For each age the number of children is given in whom hormone excretion was measured together with the mean values and the highest and lowest of the values found for every age group. Table 2 demonstrates the results obtained from boys according to skeletal age, and table 3 shows the hormone pattern of the girls arranged according to skeletal age. Results obtained from boys, then those of the girls are discussed and finally the two groups are compared.

\section{Results obtained from boys}

From the fifth to the tenth year of age we found a slow increase in the excretion of androsterone and etiocholanolone, the excretion of androsterone is higher than that of etiocholanolone. In the next years we found a high increase in the excretion of both steroids, the increase of etiocholanolone being higher than that of androsterone. With increasing age the excretion of etiocholanolone reaches that of androsterone and surmounts it.

Comparing mean values obtained from boys older than 16 years with those found for adults (1) we found that the hormone excretion increases, rising up to the age of 20 and some years later. Dehydroepiandrosterone shows 
Tab. 2

Steroidhormone excretion of boys in $\mu \mathrm{g} / 24 \mathrm{~h}$ following the bone age of the persons

\begin{tabular}{|c|c|c|c|c|c|c|c|c|c|c|c|c|}
\hline $\begin{array}{l}\text { Age } \\
\text { (Years) }\end{array}$ & $\mathbf{n}$ & 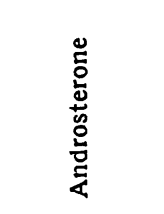 & 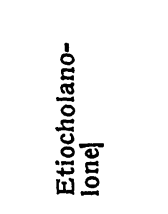 & 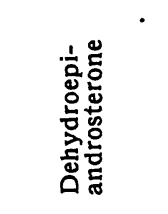 & 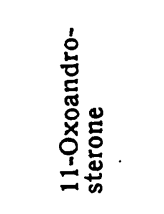 & 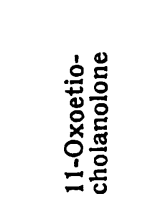 & 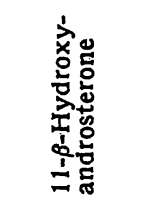 & 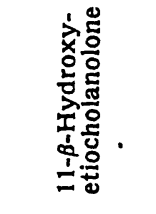 & 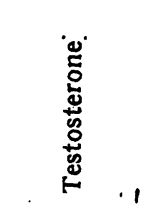 & 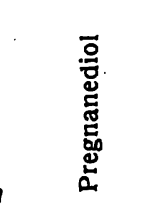 & 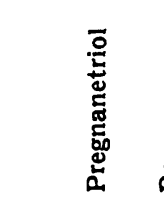 & 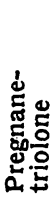 \\
\hline 4 & 6 & $(14-195)$ & $(0-250)$ & $(0-80)$ & $\left(0^{75}-150\right)$ & $(30-118$ & $\begin{array}{l}5 \\
-80)\end{array}$ & $(40-290)$ & $(1 \stackrel{9}{-20})$ & $(10-142)$ & $(20-160)$ & 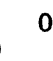 \\
\hline 5 & 9 & $\begin{array}{c}130 \\
(40-200)\end{array}$ & $(10-260)$ & $(0-120)$ & $(20-200)$ & $(50-270)$ & $(0-80)$ & $(20-80)$ & $(0-10)$ & $(0-200)$ & $(20-160)$ & 0 \\
\hline 6 & 9 & $(90-480)$ & $(0-206)$ & $\begin{array}{l}36 \\
(0-200)\end{array}$ & $\begin{array}{l}141 \\
(0-320)\end{array}$ & $\begin{array}{c}166 \\
(40-340)\end{array}$ & $(0-80)$ & $\left(10^{47}-70\right)$ & $(0-20)$ & $(10-480)$ & $(20-450)$ & 0 \\
\hline 7 & 9 & $\begin{array}{c}(90)-400) \\
(80-370)\end{array}$ & $(0-230)$ & $\begin{array}{c}32 \\
(0-110)\end{array}$ & $\begin{array}{c}80 \\
(0-210)\end{array}$ & $(30-280)$ & $(10-340)$ & $(0-140)$ & $(0-10)$ & $\begin{array}{c}109 \\
(0-280)\end{array}$ & $(20-440)$ & 0 \\
\hline 8 & 12 & $(30-350)$ & $\begin{array}{c}78 \\
(0-390)\end{array}$ & $(0-180)$ & $(10-260)$ & $(50-430)$ & $(0-120)$ & $\begin{array}{r}62 \\
(0-180)\end{array}$ & $(0-20)$ & $(10-34$ & $(20-550)$ & 0 \\
\hline 9 & 5 & $(200-330)$ & $\begin{array}{c}215 \\
(130-270)\end{array}$ & $(0-100)$ & $\begin{array}{c}185 \\
(0-380)\end{array}$ & $\begin{array}{c}239 \\
(50-390)\end{array}$ & $(0-100)$ & $(80-120)$ & $(10-20)$ & $\begin{array}{c}302 \\
(10-550)\end{array}$ & $(60-380)$ & 0 \\
\hline 10 & 27 & $(60-780)$ & $\begin{array}{c}123 \\
(20-270)\end{array}$ & $(0-430)$ & $(30-440)$ & $(10-600)$ & $(10-230)$ & $(0-280)$ & $(0 \stackrel{14}{60})$ & $(20-480)$ & $(10-780)$ & 0 \\
\hline 11 & 27 & $(70-1370)$ & $(20-580)$ & $\left(1 \frac{108}{400}\right)$ & $\begin{array}{c}116 \\
(20-290)\end{array}$ & $(20-630)$ & $(0-120)$ & $(20-220)$ & $\left(0^{21}-90\right)$ & $(20-380)$ & $\left(40^{134}-560\right)$ & ) \\
\hline 12 & 20 & $(90-1190)$ & $\begin{array}{c}387 \\
(120-1240)\end{array}$ & $\begin{array}{c}108 \\
(10-460)\end{array}$ & $\begin{array}{c}177 \\
(40-340)\end{array}$ & $(60-530)$ & $\left(20 \frac{95}{430)}\right.$ & $(30-430)$ & $\left(10 \frac{24}{-160)}\right.$ & $(70-600)$ & $(20-350)$ & ) \\
\hline 13 & 30 & $\begin{array}{c}630 \\
(100-2520)\end{array}$ & $(0-2000)$ & $(0-800)$ & $(30-740)$ & $(30-800)$ & $(0-160)$ & $(30-320)$ & $\left(10 \frac{32}{-280)}\right.$ & $(40-630)$ & $(50-810)$ & כ) \\
\hline 14 & 16 & $(150-1380)$ & $(80-2025)$ & & $(0 \stackrel{210}{480)}$ & $\left(50^{325}-725\right)$ & $\left(10 \frac{85}{-210}\right)$ & $(20-410)$ & $(10-230)$ & $(120-530)$ & $(0-1310)$ & ) \\
\hline 15 & 10 & $\begin{array}{c}1530 \\
(300-3270)\end{array}$ & $\begin{array}{c}1280 \\
(340-3960)\end{array}$ & $\begin{array}{c}190 \\
(30-680)\end{array}$ & $(90-580)$ & $(60-1140)$ & $(30-450)$ & $(80-500)$ & $(10-200)$ & $(80-800)$. & $\left(120{ }^{910}-1810\right)$ & 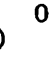 \\
\hline $\begin{array}{c}\text { more } \\
\text { than } \\
16\end{array}$ & 11 & $\begin{array}{c}1850 \\
(260-4500)\end{array}$ & $\begin{array}{c}2300 \\
(130-4450)\end{array}$ & $\begin{array}{c}512 \\
(120-2630)\end{array}$ & $(208-1270)$ & $(300-2100)$ & $(90-490)$ & $\begin{array}{c}310 \\
(130-568)\end{array}$ & $\begin{array}{c}83 \\
(50-150)\end{array}$ & $\begin{array}{c}1242 \\
(240-2420)\end{array}$ & $\begin{array}{c}1530 \\
(110-2110)\end{array}$ & 0 \\
\hline
\end{tabular}

Tab. 3

Steroidhormone excretion of girls in $\mu \mathrm{g} / 24 \mathrm{~h}$ following the bone age of the persons

\begin{tabular}{|c|c|c|c|c|c|c|c|c|c|c|c|}
\hline $\begin{array}{c}\text { Age } \\
\text { (Years) }\end{array}$ & $\mathrm{n}$ & 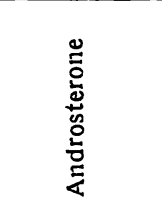 & 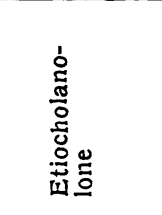 & 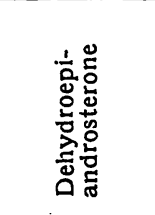 & 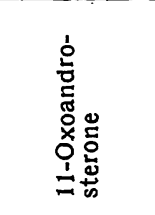 & 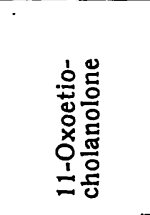 & 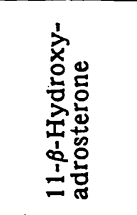 & 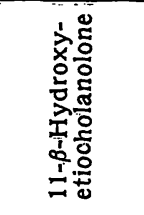 & 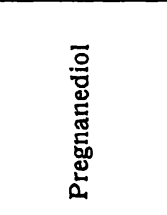 & 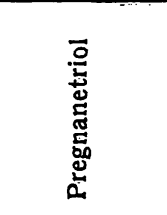 & 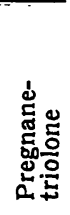 \\
\hline 5 & 5 & $(22-138$ & $(8 \stackrel{29}{-5}$ & 4 & 26 & 11 & 19 & & 33) & 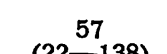 & \\
\hline 6 & 8 & $\begin{array}{c}(22-138) \\
78 \\
(22-212)\end{array}$ & $\begin{array}{c}(8-52) \\
95-232)\end{array}$ & $\begin{array}{c}(0-12) \\
17\end{array}$ & $\begin{array}{c}101 \\
(36-301)\end{array}$ & $\begin{array}{c}(35-181) \\
(90-410)\end{array}$ & $\begin{array}{l}-46) \\
1 \\
-60)\end{array}$ & & $\begin{array}{l}(25-133) \\
102 \\
(29-252)\end{array}$ & 1) & \\
\hline 7 & 5 & $\begin{array}{c}276 \\
(86-525)\end{array}$ & $(11-180)$ & $\begin{array}{c}66 \\
(10-146)\end{array}$ & $\begin{array}{l}103 \\
(36-175)\end{array}$ & $\begin{array}{c}154 \\
(107-312)\end{array}$ & 36 & $(37-$ & 114 & 203 & \\
\hline 8 & 7 & $\begin{array}{c}268 \\
(61-864)\end{array}$ & $(5-272)$ & $(4-10)$ & $(35-141)$ & $(36-320)$ & & & $\begin{array}{l}03124 \\
44-21\end{array}$ & $(16-300)$ & 0 \\
\hline 9 & 4 & $\begin{array}{c}158 \\
(4-216)\end{array}$ & $\begin{array}{c}197 \\
(160-253)\end{array}$ & $(10-52)$ & $(25-195)$ & $\begin{array}{c}326 \\
(222-455)\end{array}$ & $40^{141)}$ & 102 & 136 & 141 & 0 \\
\hline 10 & 9 & 257 & 218 & 34 & $(25-183)$ & $(222-456)$ & $(25-1(1)$ & (20 73 & $(69-265)$ & $(66-297)$ & 0 \\
\hline 11 & 3 & 264 & 265 & 31 & $(27-675)$ & $(44-366)$ & $(25-111)$ & $(28-202)$ & $\begin{array}{c}(60-372) \\
239\end{array}$ & $(65-775)$ & $\mathbf{0}$ \\
\hline 12 & 16 & $(61-1330)$ & $(140-390)$ & $6733)$ & $3-112)$ & $(87-645)$ & $(22-57)$ & $\overrightarrow{95}^{210)}$ & $(216-266)$ & $210-507)$ & 0 \\
\hline 13 & 7 & $\begin{array}{c}648 \\
(160-1820)\end{array}$ & 481 & $(3-185)$ & $(28-705)$ & $(40=1680)$ & (13-13 & 96 & 264 & $31-2080)$ & 0 \\
\hline 14 & 26 & $(160-1820)$ & $(80-1400)$ & $(15-1550)$ & $(25-755)$ & $(56-640)$ & $\begin{array}{c}(10-530) \\
118\end{array}$ & $(11-368)$ & & $(60-1530)$ & 0 \\
\hline 15 & 28 & $(130-57800)$ & $\begin{array}{c}(94-4282) \\
1040\end{array}$ & $(11-928)$ & $(16-1450)$ & $(12-1500)$ & $(4-615)$ & $(16-552)$ & $(36-1720)$ & $(22-3348)$ & 0 \\
\hline 16 & 9 & $\begin{array}{c}(90-2000) \\
1410 \\
(126-3570)\end{array}$ & $\begin{array}{c}(60-3880) \\
1574 \\
(664-4786)\end{array}$ & $\begin{array}{c}(10-735) \\
350 \\
(65-1200)\end{array}$ & $\begin{array}{c}(45-945) \\
367 \\
(170-750)\end{array}$ & $\begin{array}{c}(62-760) \\
391 \\
(80-908)\end{array}$ & $\begin{array}{c}(22-430) \\
134 \\
(0-665)\end{array}$ & $\begin{array}{c}(25-306) \\
285 \\
(39-990)\end{array}$ & $\begin{array}{c}(180-1570) \\
817 \\
(246-1440)\end{array}$ & $\begin{array}{c}(160-2120) \\
(270-1550)\end{array}$ & 0 \\
\hline
\end{tabular}

an increase similar to androsterone and etiocholanolone but the values are much lower.

In the urines of prepuberal boys we could find only a slight increase in dehydroepiandrosterone excretion, from $25 \mu \mathrm{g}$ at the age of 5 years to $65 \mu \mathrm{g}$ at 10 years of age. At the age of 13 we found a slight maximum of $120 \mu \mathrm{g}$ followed by a small decrease at fourteen to $100 \mu \mathrm{g}$ and an increase in the following years to $580 \mu \mathrm{g}$ at the age of 16.

In the age from five to ten years we did not find any value higher than $20 \mu \mathrm{g}$ for testosterone. In the following years there commences a slight increase of the mean values (figure 1). The mean values found by us correspond well with the investigation of KNORR (15). Whereas the increase in the mean value is slight, it is interesting that we found relatively high values for one or two boys at the age of eleven and twelve years whereas the absolute highest single value was found for boys in the age of 13 and 14. In the years of 14 and 15 we found the highest increase in the mean value. At the age of fifteen the testosterone excretion approaches that found for adults being about $80 \mu \mathrm{g} / \mathrm{d}$.

The 11-hydroxy-17-oxosteroids also show an increase in the age from five to sixteen, but the increase is less than 


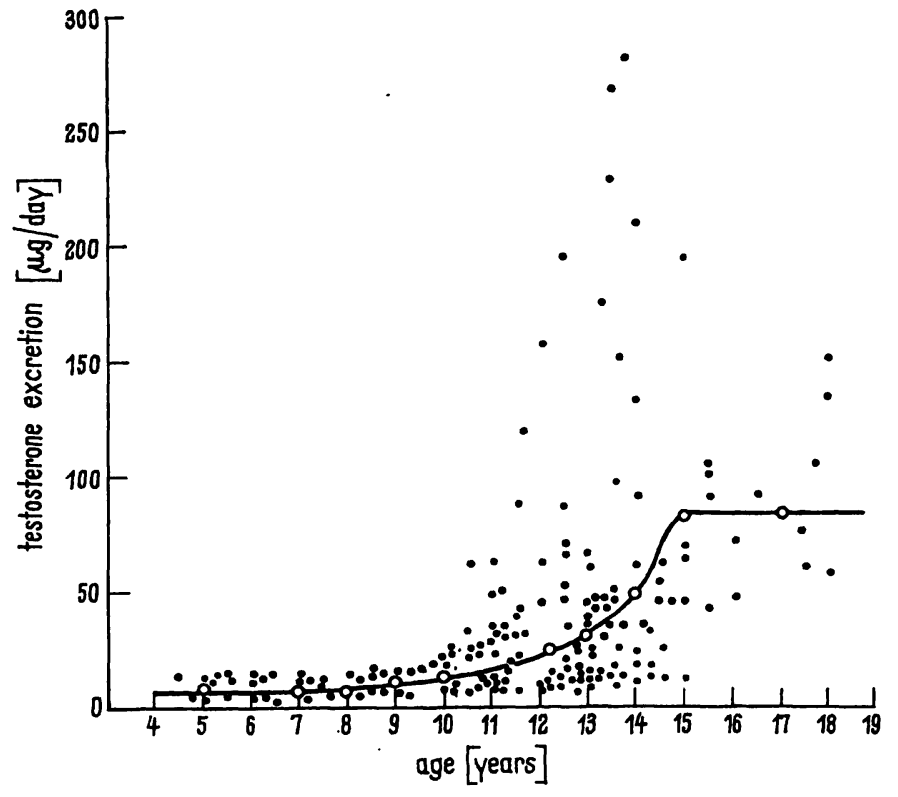

Fig. 1

Testosterone excretion of healthy boys in $\mu \mathrm{g} / \mathrm{day}$. There is given the sum of free testosterone and of testosterone bound on glucuronic and sulfuric acid. - Single, $O$ Mean Values

that of the androgens (table 5). We found the highest increase in the age from 14 to 16.

The increase of the pregnanes is parallel to that of the androgens, the amount being less. This is demonstrated by the relation of the amount of the pregnanes compared to the sum of androsterone and etiocholanolone (table 5).

Results obtained from girls and comparison of the bormone excretion of boys with that of girls

The results received from the urines of girls are nearly the same as those received for boys but the rise commen- ces at an earlier age and values for testosterone did not exceed $25 \mu \mathrm{g} / \mathrm{d}$.

We found a daily urinary excretion of $70 \mu \mathrm{g}$ for androsterone and $30 \mu \mathrm{g}$ for etiocholanolone at the age of five years. The excretion rises slightly until the age of eight, then thcre is a rapid increase, reaching values of about $1000 \mu \mathrm{g}$ daily at the age of 14 years. When we compare the results obtained from boys with those of girls we see that the excretion in the prepuberal period is less among girls than among boys. At the age of 9 the excretion of 11-deoxy-17-oxosteroids in girls surmounts that of boys, but at the age of 11 the androgen synthesis in boys strats to increase, and between the 14th and 15th years of age the excretion of 11-deoxy-17-oxosteroids of boys surmounts that of the girls (figure 2).

For dehydroepiandrosterone we found lower values for girls than for boys during all periods of somatic growth and body maturation, whereas the excretion of the 11-hydroxy-17-oxosteroids is nearly the same for boys and girls. On the other hand the urinary excretion of the pregnanes is higher in girls than in boys till to the age of 15 (figure 3 ). We could not find pregnanetriolone in any urine, this steroid being excreted only in cases of 21-hydroxylase deficiency.

The following results were obtained from persons without clinical signs of endocrine disease but with a hormone excretion pattern which was so different from that of the other children of the same age that it was necessary to exclude these values from the determination of the mean value and the range (table 4).

$\mathrm{K}$. W.: This was a small 8 year old boy, skeletal age 4 years 6 months. The urinary excretion of 11-deoxy-17oxosteroids as well as that of the pregnanes was elevated.

Tab. 4

Steroidhormone excretion (in $\mu \mathrm{g} /$ day) of some children with an abnormal steroid pattern but without clinical signs of an endocrine disease

\begin{tabular}{|c|c|c|c|c|c|c|c|}
\hline \multirow{2}{*}{$\begin{array}{l}\text { Name } \\
\text { chronological age } \\
\text { (years/month) } \\
\text { bone age }\end{array}$} & \multirow{2}{*}{$\begin{array}{c}\text { K. W. } \sigma^{\prime \prime} \\
\begin{array}{c}8 / 3 \\
4 / 6\end{array}\end{array}$} & \multicolumn{2}{|c|}{ R. F. o } & \multirow{2}{*}{$\begin{array}{c}\text { V.R. } \sigma \\
12 / 6 \\
12 / 6\end{array}$} & \multirow{2}{*}{ 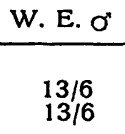 } & \multirow{2}{*}{$\begin{array}{l}\text { F. E. } ᄋ \\
13 / 6 \\
11 / 10\end{array}$} & \multirow{2}{*}{$\begin{array}{c}\text { St. Ch. } 9 \\
\begin{array}{c}14 / 1 \\
14 / 0\end{array}\end{array}$} \\
\hline & & $\begin{array}{c}11 / 3 \\
11\end{array}$ & $\begin{array}{l}11 / 8 \\
11 / 8\end{array}$ & & & & \\
\hline \multirow{5}{*}{$\begin{array}{l}\text { Androsterone } \\
\text { Etiocholanolone } \\
\text { Dehydroepi- } \\
\text { androsterone } \\
11-\text { - } \\
11-\text { Oxoandrosterone } \\
\text { cholanolone } \\
11-\beta \text {-Hydroxy- } \\
\text { androsterone } \\
11-\beta-H y d r o x y- \\
\text { etiocholanolone } \\
\text { Testosterone } \\
\text { Pregnanediol } \\
\text { Pregnanetriol }\end{array}$} & $\begin{array}{r}150 \\
60\end{array}$ & $\begin{array}{l}546 \\
578\end{array}$ & $\begin{array}{l}1590 \\
1900\end{array}$ & $\begin{array}{l}800 \\
750\end{array}$ & $\begin{array}{l}294 \\
372\end{array}$ & $\begin{array}{l}4340 \\
2090\end{array}$ & $\begin{array}{l}528 \\
644\end{array}$ \\
\hline & $\begin{array}{r}6 \\
335\end{array}$ & $\begin{array}{r}343 \\
60\end{array}$ & $\begin{array}{l}720 \\
495\end{array}$ & $\begin{array}{r}1490 \\
200\end{array}$ & $\begin{array}{l}89 \\
61\end{array}$ & $\begin{array}{l}190 \\
306\end{array}$ & $\begin{array}{l}36 \\
16\end{array}$ \\
\hline & 650 & 108 & 610 & 65 & 54 & 276 & 12 \\
\hline & 220 & 20 & 250 & 12 & 50 & 276 & 12 \\
\hline & $\begin{array}{r}330 \\
15 \\
380 \\
630\end{array}$ & $\begin{array}{r}66 \\
49 \\
172 \\
95\end{array}$ & $\begin{array}{l}363 \\
320 ! \\
865 \\
985\end{array}$ & $\begin{array}{r}30 \\
195 \\
83 \\
240\end{array}$ & $\begin{array}{l}181 \\
226 \\
142 \\
100\end{array}$ & $\begin{array}{r}85 \\
20 \\
573 \\
598\end{array}$ & $\begin{array}{r}16 \\
8 \\
40 \\
22\end{array}$ \\
\hline
\end{tabular}

Tab. 5

The relationships between some steroids excreted in the urine of boys

\begin{tabular}{|c|c|c|c|c|c|c|c|c|c|c|c|c|c|}
\hline age in years & 4 & 5 & 6 & 7 & 8 & 9 & 10 & $11^{\circ}$ & 12 & 13 & 14 & 15 & 16 \\
\hline $\begin{array}{c}\text { - Androsterone } \\
\text { Etiocholanolone }\end{array}$ & 1.3 & 1.67 & 2.2 & 1.75 & 1.9 & 1.3 & 1.8 & 1.22 & 1.0 & 0.91 & 0.96 & 1.2 & 0.8 \\
\hline$\frac{\text { 11-Desoxy-17-oxo-steroids }}{\text { 11-Hydroxy-17-oxo-steroids }}$ & 0.6 & 0.71 & 0.76 & 0.9 & 0.65 & 0.85 & 0.77 & 1.3 & 1.12 & 1.8 & 1.73 & 2.18 & 1.85 \\
\hline$\frac{\text { Androsterone }+ \text { Etiocholanolone }}{\text { Pregnanediol + Pregnanetriol }}$ & 1.37 & 1.47 & 0.97 & 1.22 & 1.04 & 0.97 & 1.41 & 2.04 & 2.04 & 2.00 & 1.85 & 1.96 & 1.50 \\
\hline$\frac{\text { Pregnanediol }+ \text { Pergnanetriol }}{\text { Dehydroepiandrosterone }}$ & 6.9 & 5.7 & 8.4 & 7.7 & 8.5 & 12.0 & 3.66 & 2.56 & 3.5 & 3.7 & 6.6 & 7.6 & 5.3 \\
\hline$\frac{\text { Dehydroepiandrosterone }}{\text { Testosterone }}$ & 2.0 & 3.0 & 4.0 & 4.5 & $3.5^{\circ}$ & 3.5 & 4.8 & 5.1 & 4.5 & 5.6 & 2.0 & 2.4 & 6.1 \\
\hline
\end{tabular}




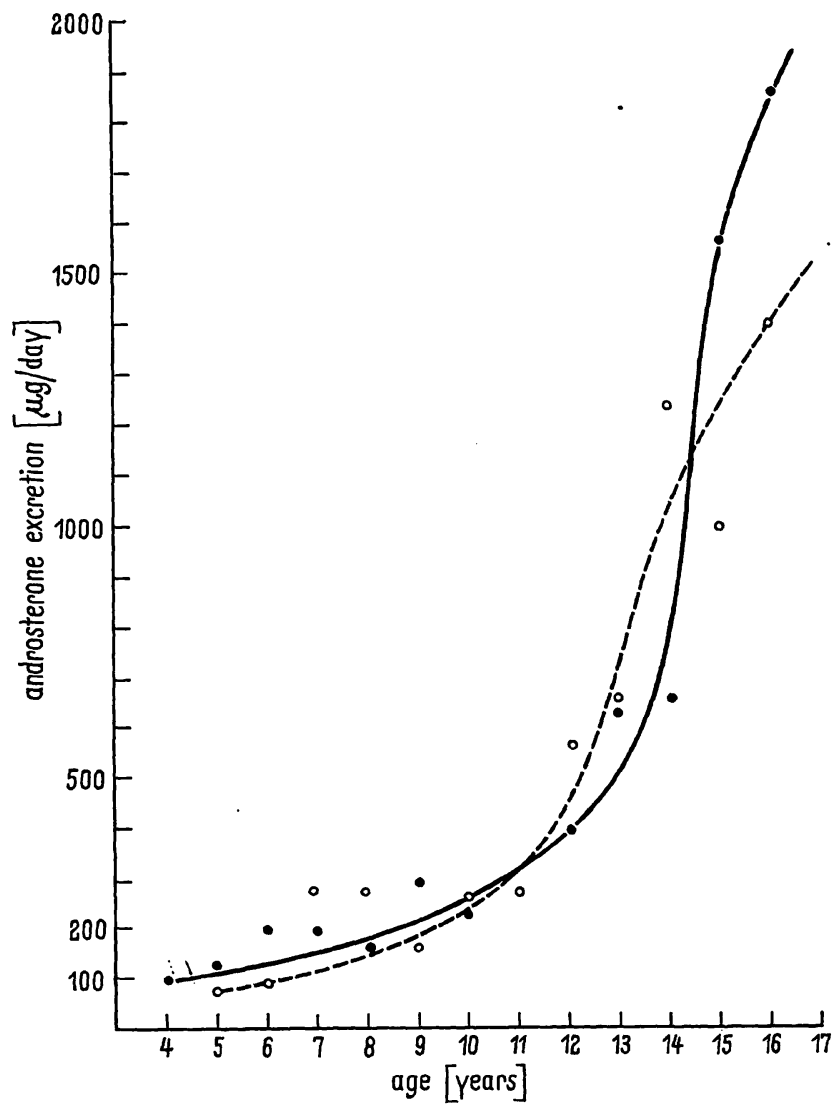

Fig. 2

Androsterone excretion of healthy boys (--.) and girls $\left(\mathrm{O}-\mathrm{-O}^{-} \mathrm{O}\right)$ The values given in $\mu \mathrm{g} /$ day are ordered following the bone age of the persons

R. F.: This boy showed a normal stature, the skeletal age was 11 years and 3 months, the same as the chronological age. We collected the first 24 -h-urine specimen at age $11^{3} / 12$ years. In this urine we found a normal level of pregnanes and 11-hydroxy-17-oxosteroids but a high excretion of androgens. Testosterone was excreted in an amount of $50 \mu \mathrm{g} / \mathrm{d}$. Half a year later we examined the urinary steroid pattern for a second time. At this time skeletal age still corresponded to chronological age. Testes development was at the second stage according to the tables of TANNER (16). However, at this time we found a large increase for all steroids in comparison with the first hormone level examined. The value of testosterone, $320 \mu \mathrm{g} / \mathrm{d}$ was the highest we had ever found. In order to assure that this result was not feigned by another substance gas-liquid-chromatography was combined with thin layer chromatography $(12,17)$ and the same value was obtained.

V. R.: This boy aged $12^{6} / 12$ years, skeletal age the same as chronological age, also showed an interesting hormone pattern. We found very high values for dehydroepiandrosterone and testosterone whereas the other steroids were excreted in normal amounts.

W. R.: Contrary to the hormone pattern described above, this $131 / 2$ year old boy had a low excretion of all steroids except testosterone which reaches one of the highest values we ever found.

F. E. : A 13 year old girl, skeletal age 11 years 10 months. The values found for all steroids were high and the re- sults obtained from androsterone and etiocholanolone were among the highest we ever estimated, whereas the value for testosterone was under $20 \mu \mathrm{g}$, pregnanetriolone was found to be absent.

St. Ch.: For this $14^{11} / 12$ year old girl, with a slightly retarded skeletal age of 14 years, we found very low values overail. Until now, we have not been able to explain the cause of these unusual hormone patterns and have not been able to get second urines from the same children. We show you these results demonstrating great differences as an argument for our opinion that the analysis of one urine is not enough to judge the hormone excretion of one individual.

\section{Discussion}

At first we must consider whether the values given by us were real normal values. We must pay attention to two points :

Accuracy of the metbod. We think that the accuracy of our method with $\pm 10 \%$ is exact enough for routine analyses. All values were corrected using a calibration curve which also eliminated systematic losses.

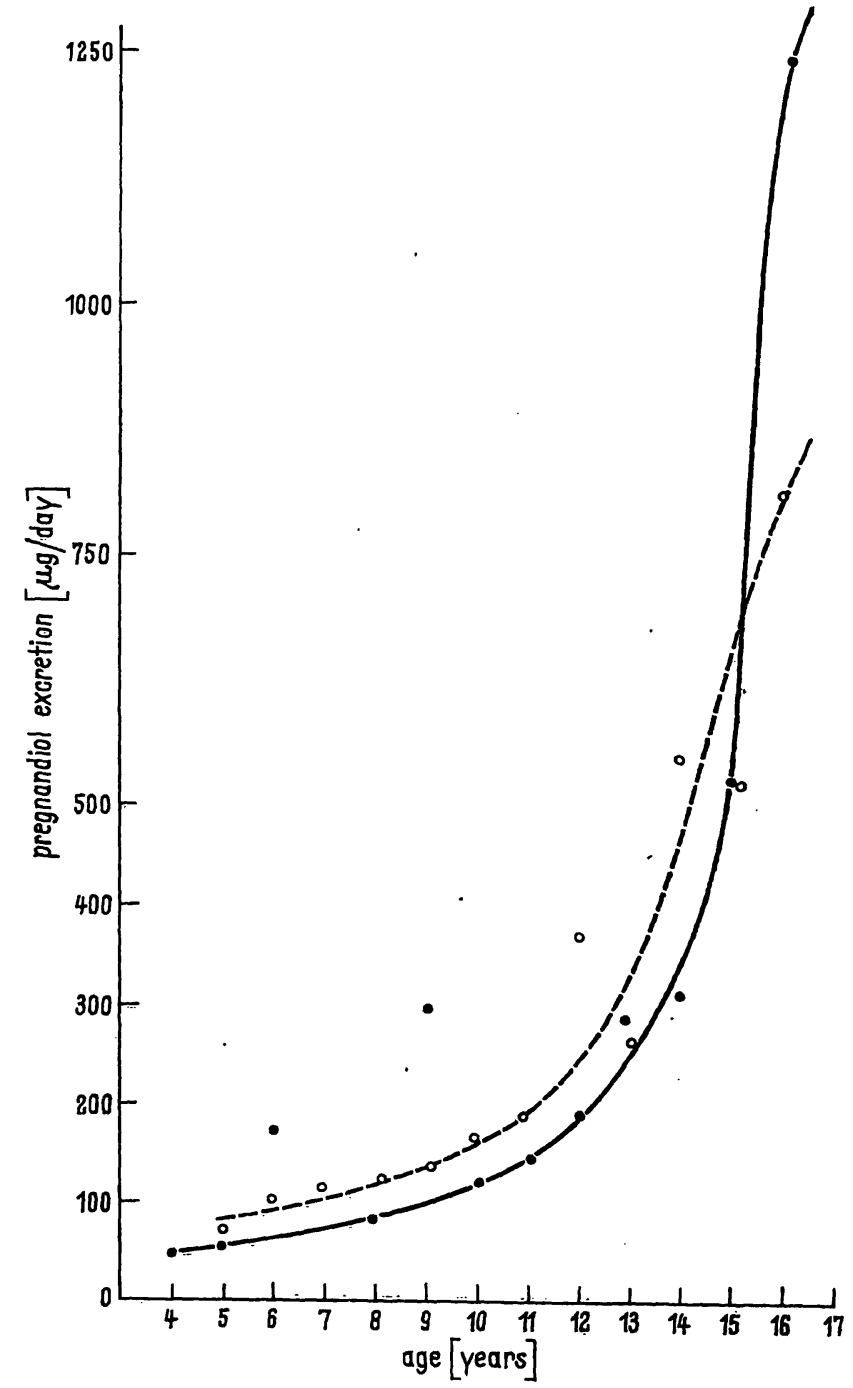

Fig. 3.

Excretion of pregnanediol in the urine of healthy boys (०-0) and girls (0-- - O) in $\mu \mathrm{g} / \mathrm{day}$ 
Selection of the children. For our investigation we collected the urines from boys and girls of 7 different boarding schools. A continuous increase of the mean values with advancing years of age could be observed. The only substance to show a maximum was dehydroepiandrosterone, with a slight peak at thirteen years. This maximum is based on a great number of persons and seems to be real. Comparing our results with those obtained by the other authors cited before (2-6) all these values lie in the range given by us, but the mean, if given, differs from ours, this is due to the small population sample in which the other investigators examined hormone patterns. The large number of children in whom we estimated the daily urinary steroid excretion leads us to think that the values obtained are real normal values.

The following relationships were found:

1. The mean value for androsterone divided by the mean value for etiocholanolone (fig. 4): For the young boys (fig. 4a) as well as for the young girls (fig. 4b) we found a higher excretion of androsterone than of etiocholanolone. During body maturation the increase in the excretion is higher for etiocholanolone than for androsterone and we found a higher excretion of etiocholanolone than that of androsterone in the urinary hormone pattern of adults. However, it is very interesting that this factor changes only once for boys, whereas for girls this relation varies very often. One must wonder that this correlation of $5-\alpha-\mathrm{H}$ to $5-\beta-\mathrm{H}$ was not observed for the 11-hydroxy-17-oxo-steroids.

2. Lastly some other relations should be discussed. When we at first evaluated our results obtained from five boys
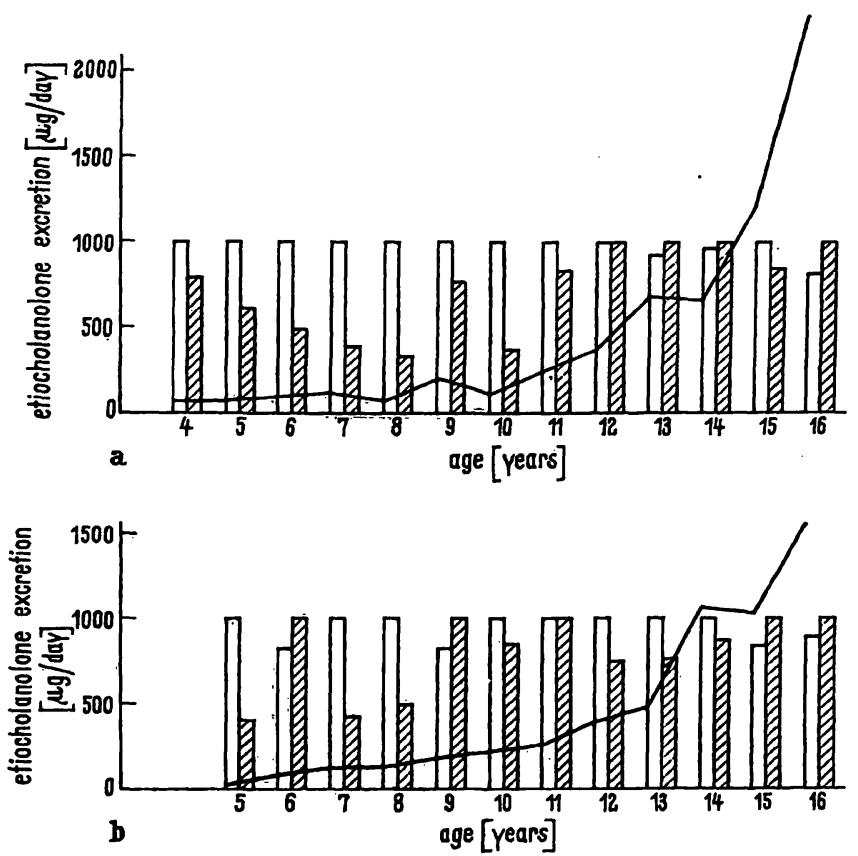

Fig. 4a

The relationship between androsterone (white bars $=100$ ) and etiocholanolone (black bars) in boys. Solid line: excretion of etiocholano-

Fig. 4b

The relationship between androsterone (white bars $=100$ ) and etiocholanolone (black bars) in girls. Sollid line: excretion of etiocholano- of each age, we found a maximum in the excretion of pregnanetriol at the age of 8 years, then one of dehydroepiandrosterone at the age of 12 years and two years later the highest excretion of testosterone. Estimating a greater number of urines the mean value is calculated by summarizing the values of persons with high, medium and low steroid excretions. We think that the relation between the different steroids is significant for the present state of development rather than the absolute amount of one steroid alone. So we compared the relations between 11-deoxy-17-oxosteroids and pregnanes, pregnanes and dehydroepiandrosterone, dehydroepiandrosterone and testosterone (fig. $5 a-5 c$ ).

The results we obtained are given in table 5. Considering the correlation between 11-deoxy-17-oxosteroids and pregnanes there is a great difference in the values obtained before and after the age of ten years.

The boys younger than 10 excrete a much higher amount of pregnanes in comparison to androsterone and etiocholanolone than in later life. The absolute amount of excreted pregnanes is given by the line in the diagram of figure $5 \mathrm{a}$.
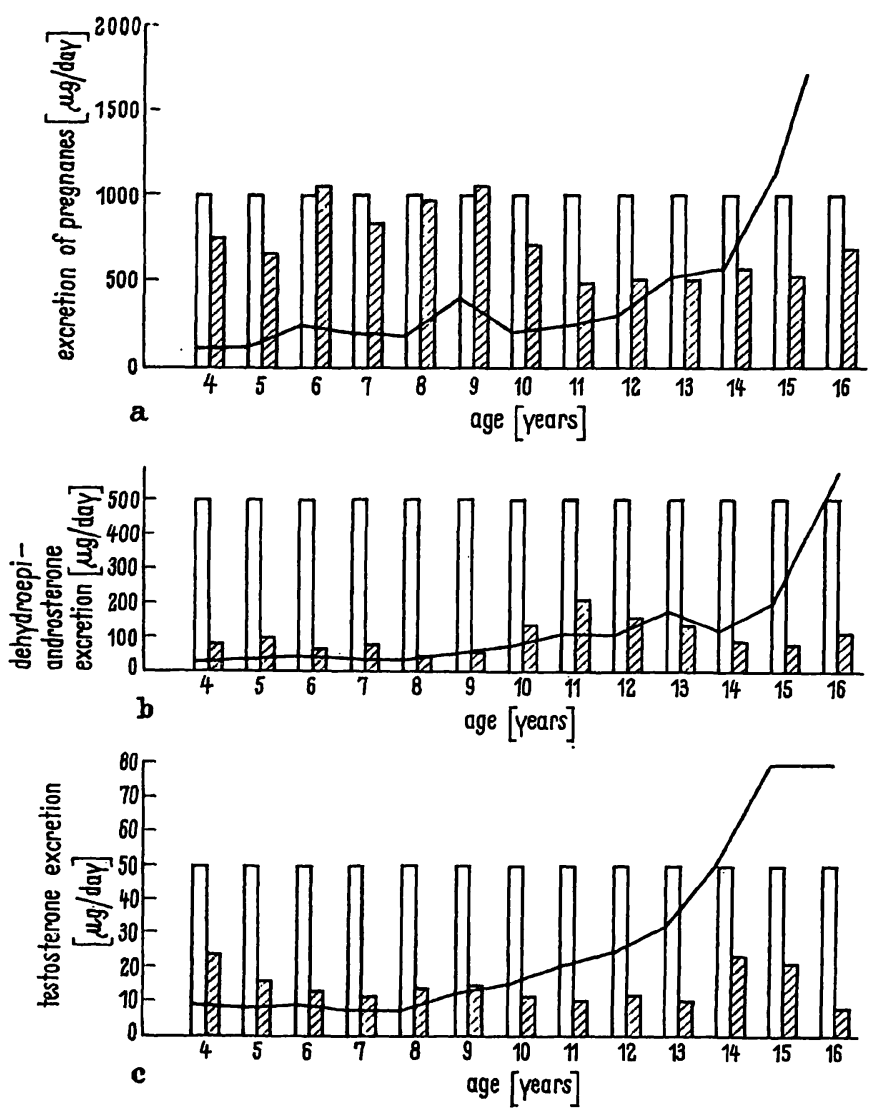

Fig. 5 a

The relationship between the sum of androsterone and etiocholanolone (white bars $=100$ ) and the sum of pregnanes (black bars) in boys. Solid line: excretion of pregnanes

Fig. 5 b

The relationship between dehydroepiandrosterone (black bars) and the sum of pregnanes (white bars $=100$ ) in boys. Solid line: excretion of dehydroepiandrosterone

Fig. $5 \mathrm{c}$

The relationship between dehydroepiandrosterone (white bars $=100$ ) and testosterone (black bars) in boys. Solid line: excretion of testosterone 
We found two changes for the relations between pregnanes and dehydroepiandrosterone in the course of body maturation. Commencing with the tenth year of age the excretion of dehydroepiandrosterone increases more than that of the pregnanes and at the age of eleven we found the highest excretion of dehydroepiandrosterone in correlation with that of the pregnanes. In the following years the excretion of dehydroepiandrosterone is diminished in correlation to that of the pregnanes, whereas the absolute amount of dehydroepiandrosterone (given by the line in the diagram of figure $5 \mathrm{~b}$ ) increases.

The correlation between dehydroepiandrosterone and testosterone changes at the age of 14 and 15 , where we found the highest increase in the testosterone excretion. At an age of 15 we found a mean value for testosterone corresponding with that of the adults. The mean value of testosterone is given by the line in the diagram of figure $5 \mathrm{c}$.

Comparing these results, it is possible that the changes we observed were caused by a "maturation" of enzymes. In our investigation we cannot estimate the absolute amount of one enzyme but we think that the changes in the hormone pattern are caused by changes in the pattern of the enzymes responsible for the production of the steroids. Analysing, only one urine however, we cannot distinguish between steroids produced by the adrenals and those formed in the gonads, nevertheless we think that the greatest amount of the 11-hydroxy-17oxosteroids, of pregnanes and also of androsterone, etiocholanolone and dehydroepiandrosterone was produced by the adrenals, unlike testosterone which is mostly formed by the testes.

Considering the results discussed above, we conclude that under ten years, the total enzyme activity responsible for the formation of progesterone and 17- $\alpha$-hydroxyprogesterone is relatively higher than the 17-desmolase, while after ten years the 17-desmolase is more active. Therefore we find the highest increase in the excretion of dehydroepiandrosterone up to the age of 11, when the activity of the testes and the enzymes responsible for the origin of testosterone increase. We found the highest testosterone excretion at the age of 15.

\section{Ackenowledgement}

The authors express their gratitude to the chairmen and instructors at the boarding schools for their assistance in the collection of urines.

\section{Literature}

1. Cawley, L. P., B. O. Musser and H. A. Tretbar, Amer. J. Clin. Path., 48, 216 (1967). - 2. Tanner, J. M. and D. Gupta, J. Endocr. 42, 139 (1968). - 3. TELLER, W. M., Z. exper. Med., 142, 222 (1967). - 4. Blunck, W., Fortschr. Med., 85, 23 (1967). -

5. Vesterganid, P., Acta endocr. K'hvn, 49, 436 (1965). 6. Paulsen, E. P., E. H. Sobel and M. S. Shafran, J. clin. Endocr. Springfield 26, 329 (1966). - 7. Greulich, W. W. and S. I. PyLE, Radiographic Atlas of Skeletal Development of the Hand and Wrist, London, University Press (1959). - 8. GreisPACH, this journal 7, 379 (1969). - 9. LuUKKaInen, T., W. J. A. van den Heuver, E. D. A. HaAthi and E. C. Horning,
Biochim. biophysica Acta, Amsterdam, 52, 599 (1961). - 10. Horning, E. C., M. G. Horning, N. Ikekawa, E. M. Chambaz, P. J. JAAKONMAKI and C. J. W. Brooks, J. Gaschromat., 5, 283 (1967). - 11. GleispaCh, H., Z. analyt. Chem. 243, 294 (1968). 12. GlerspaCH, H., Chromat., 2, 262 (1969). - 13. GleispaCH, H., B. Podolsky, W. Hohenwallner and H. Berger, this journal 7, 592 (1969). - 14. Curtrus, H. CH. and M. Mülíer, J. Chromat., 30, 410 (1967). - 15. KNorR, D., Acta endocr., K'hvn, 54, 215 (1967). - 16. Tanner, J. M., Wachstum und Reifung des Menschen, Georg Thieme Verlag Stuttgart (1962). - 17. Curtius, H. CH. and M. Müller, J. Chromat., 32, 222 (1968).
Dr. Helmut Gleispach Universitäts-Kinderklinik A 6020 Innsbruck 